\title{
Anti -phytopathogenic Activities of Cladophora glomerata extract against plant fungi
}

\author{
Dina.Y. Mohammed* \\ Abdul-Latif M. Jawad**
}

Received 20, December, 2012

Accepted 3, March, 2014

\begin{abstract}
:
The antiphytopathogenic effects of the crude methanol extract of Cladophora glomerata (Lin.) Kützing (Cladophoraceae) which isolated from Al Rashidiya region at north of Baghdad was investigated against two type of plant fungi (Pythium altimum and Rhizoctonia solani) which causes damping off disease where isolated from covered cucumber field in Al-Alyosifia region.

Hot methanol extract showed antifungal activity against the two species of fungi in different concentrations $(10,25,50 \mathrm{mg} / \mathrm{ml})$ of extract to Cladophora glomerata as percentage inhibition $(51.63,72.8,83.71)$ and $(56.18,77.41,100)$ comparing with Pythium altimum and Rhizoctonia solani respectively .primary detection of active compounds showed that macroalgae (Cladophora glomerata) containing flavonoids,alkaloids, phenols and tannins. Our findings suggest the possibility of using the Cladophora glomerata as a novel source of natural antimicrobial agents for pharmaceutical industries.
\end{abstract}

Key words: phytopathogenic, Activities, Macro alage, extract, fungi.

\section{Introduction:}

Algae are a large and diverse group of simple, typically autotrophic organisms, ranging from unicellular to multicellular forms and fall under the category macro-algae. Algae are extremely fast growing marine and fresh water plants that can grow to considerable size up to $60 \mathrm{~m}$ in length. Micro-algae are, as the name suggests, microscopic photosynthetic organisms. Like macro algae, these organisms grow very rapidly, and are found in both marine and fresh water environment[1].

Algae are useful in numerous therapeutic applications. Algae have been used for centuries in Asian countries, as remedy to cure or prevent various physical ailments. Researchers found that algae contain remakeable amount of components valuable for human health. Amongst algae, those have been reported to inhibit growth of micro organisms are mostly planktonic and benthic fresh and marine water [2]. Many marine macro algae produce a variety of secondary metabolites [3].

These metabolites are mainly terpenes, alkaloids and polyphenolics, many of these compounds being halogenated [4].

Cladophora glomerata is a filamentous green alga widely distributed throughout lentic and lotic freshwaters of the world [5, 6, 7]. In general, $C$. glomerata grows attached to hard substrates in nutrient rich alkaline freshwaters, although high morphological plasticity makes classification to species level difficult[8].

\section{Materials and Methods: Collection and preparation of sample:}

*Department of Biology., College of science, University of Mustansiriyah.

**Department of Biology., College of science, University of Baghdad. 
Samplings were carried out from Al Rashidiya region in north of Baghdad city ,Iraq. Which located on longitude $44^{\circ} 20^{\prime} 15.62^{\prime \prime} \mathrm{E}$ and latitude 3336'12.29"N, during autumn 2012. Samples of $C$. glomerata were collected manually from the rock of irrigation drainage which discharge their water directly to Tigris river. The harvested macro algae were stored in plastic bags for transported to the laboratory. Voucher specimen of species were pressed and stored in 5\% formalin for identification according to [9] and [10]. Biomass was rinsed with fresh water to eliminate other materials such as sand, shells, etc. The macroalgae were stored in the laboratories and dried at $50^{\circ} \mathrm{C}$ under ventilation in an oven and then grounded by the blender.

\section{Preparation of alcoholic extract:}

The alcoholic extract was prepared by soxhelet extraction according to[11]. In this process the dried powder form of plant material extracted by using ethyl alcohol. The concentrated active constituents from macroalgae were kept in sterilized test tubes stored in refrigerator till further use. The traces of methanol were removed by keeping the tubes at $50^{\circ} \mathrm{c}$ for $1 \mathrm{hr}$.

\section{Isolation of pathogenic fungi:}

Soil samples were collected from covered cucumber field in AlAlyosifia region, The samples were taken to the laboratory for isolation within 7 days. The particles of the soil samples were put on Petri dishes with potato dextrose agar (PDA) and were incubated at $25^{\circ} \mathrm{C}$ for 2-3 days. When mycelia growth was observed, purification was carried out by cutting a small piece of media with mycelia at the edge of a colony and then transplanted onto new medium plates

\section{Antifungal Activity Assay:}

In this experiment the crude extracts of the macro algae were mixed with Potato Dextrose Agar (PDA) medium to get different concentrations $, 25,10) \mathrm{mg} / \mathrm{ml}$ and the fungal mycelia were inoculated to grow. Data on the radial growth were recorded.

Potato Dextrose agar plates were inoculated with each fungus by placing a $5 \mathrm{~mm}$ diameter disc from an actively growing culture in the centre of each plate. Six replicates were used per treatment. Fungi were also grown on non-ameliorated PDA as a control. All fungi were incubated at $25^{\circ} \mathrm{C}$ for seven days in the dark. Fungal growth (colony diameter) was measured and percentage of inhibition calculated according to the formula:

Percentage inhibition $=(C-T) \times 100 / C$ Where,

$\mathrm{C}=$ Colony diameter $(\mathrm{mm})$ of the control.

$\mathrm{T}=$ Colony diameter $(\mathrm{mm})$ of the test plate.

Percentage inhibition and analysis of variance for the different treatments were calculated.

\section{Qualitative estimation of active compounds :}

The presence of active compounds of studied macro algae were determined by adopting standard protocols [12,13].

\section{Results and Discussion: Morphological Structure of}

\section{Cladophora glomerata :}

Cladophora glomerata is green or light green, filamentous in form, attached on rock or cobble in the bed of shallow rivers. Microscopically, thalli are composed of joined cylindrical cells, with lengths of $6-20 \mu \mathrm{m}$ and widths of $4-10 \mu \mathrm{m}$ and with dichotomously branching filaments. Branches are tufted, arising singly, arbuscular, the 
branches becoming irregular in old algae. Branches are narrowed towards tips, cell walls are thick and usually lamellate. The chloroplast is in a parietal network with numerous pyrenoids. Usually it tends to stay on one spot, which makes it easy to remove (Fig. 1\&2) .

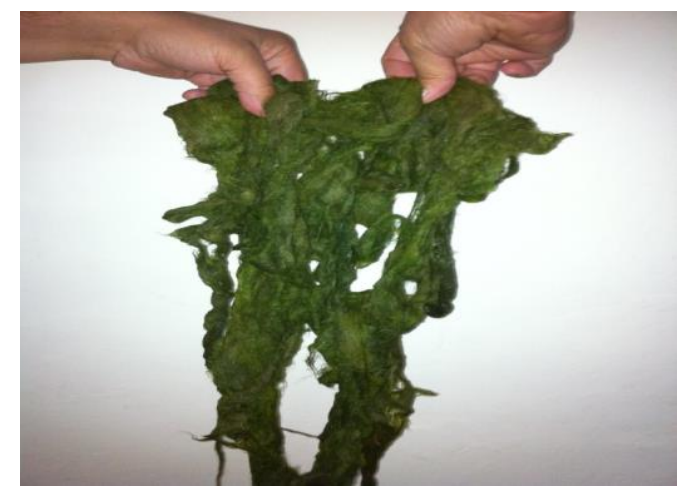

Fig. (1): Cladophora glomerata after harvested from water.

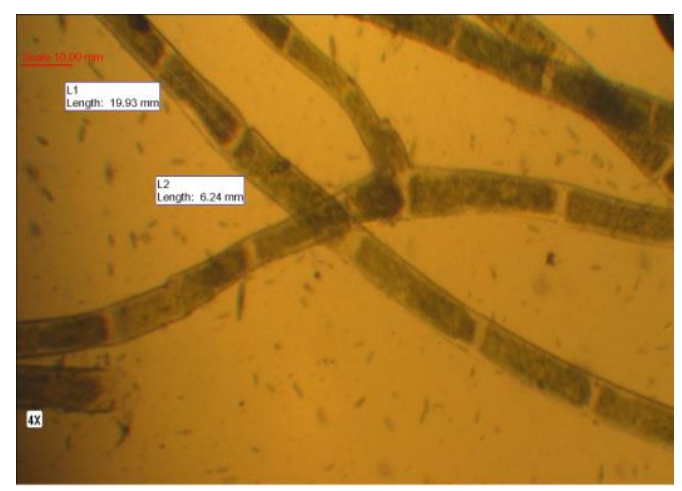

Fig. (2): Cladophora glomerata under microscope $4 \mathrm{X}$.

Two species of plant pathogenic fungi were isolated from covered cucumber field in Al-Alyosifia region ,they were (Pythium ultimum and Rhizoctonia solani) fungi were identified on the basis of morphological characteristics suggested by $[14,15]$.

\section{Evaluation of Antifungal Activity:}

The antifungal activity of Cladophora glomerata crude methanolic extracts of which isolated from Al Rashidiya region in north of Baghdad city are shown in the Table (1)and Figure $(3,4)$. The antifungal activity is ranged between (51.63\%-83.71\%) and (56.18\%-100\%) to Pythium ultimum and Rhizoctonia solani respectively at different concentrations of extract.

Table (1): Mean Percentage inhibition of different fungi at different concentrations of Cladophora glomerata extract.

\begin{tabular}{|c|c|c|c|c|}
\hline & \multicolumn{4}{|c|}{ Conc.of macroalgae extract. } \\
\hline $\begin{array}{c}\text { Name of } \\
\text { Fungi }\end{array}$ & $\begin{array}{c}10 \\
\mathrm{mg} / \mathrm{ml}\end{array}$ & $25 \mathrm{mg} / \mathrm{ml}$ & $50 \mathrm{mg} / \mathrm{ml}$ & Control \\
\hline $\begin{array}{c}\text { Pythium } \\
\text { ultimum }\end{array}$ & 51.63 & 72.8 & 83.71 & 0.00 \\
\hline $\begin{array}{c}\text { Rhizoctonia } \\
\text { solani }\end{array}$ & 56.18 & 77.41 & 100 & 0.00 \\
\hline
\end{tabular}

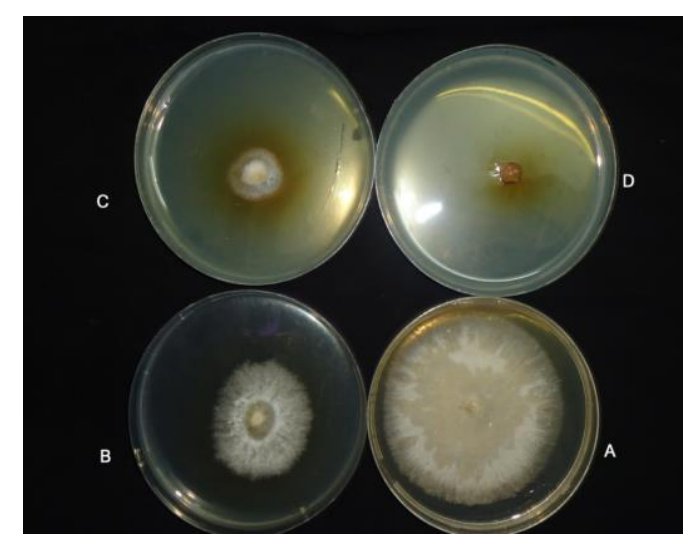

Fig. (3): percentage inhibition growth of Rhizoctonia solani in PDA plates by use methanol extract of Cladophora glomerata. A:control B:10 $\mathrm{mg} / \mathrm{ml}$ C:25 $\mathrm{mg} / \mathrm{ml}$ D:50 $\mathrm{mg} / \mathrm{ml}$.

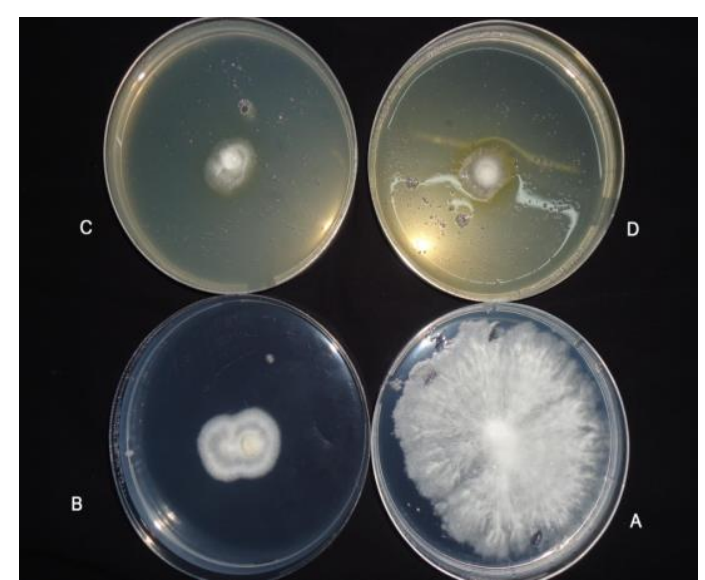

Fig. (4): percentage inhibition growth of Pythium ultimum in PDA plates by use methanol extract of Cladophora glomerata. A:control B:10 $\mathrm{mg} / \mathrm{ml} \quad$ C:25 $\mathrm{mg} / \mathrm{ml}$ D:50 $\mathrm{mg} / \mathrm{ml}$. 
The extracts and active constituents of various macroalgae have been shown to have antimicrobial activity in vitro [16]. Antimicrobial activity of marine algae from Brazil have been noticed. While [17] recorded antimicrobial activity of blue green and green algae .However and [18] studied seven algae for their antimicrobial activity against Aspergillus flavus, Aspergillus niger and Alternaria brasica.

Qualitative estimation of active compounds from the macroalgae:

The results showed presence of active compounds in methanol extract of Cladophora glomerata in the Table (2).

Table (2): Presence or absence of active compounds in Cladophora glomerata extract.

\begin{tabular}{|c|c|}
\hline $\begin{array}{c}\text { Active } \\
\text { compounds }\end{array}$ & $\begin{array}{c}\text { Presence } \\
\text { OrAbsence }\end{array}$ \\
\hline Alkaloids & + \\
\hline Glycosides & - \\
\hline Tannins & + \\
\hline Terpenoid & - \\
\hline Flavonoids & + \\
\hline Phenols & + \\
\hline Saponins & - \\
\hline
\end{tabular}

The results showed that methanolic extract of Cladophora glomerata had the Alkaloids, Tannins, phenols and Flavonoids while glycosides, terpenoids, and saponins, were absent . This results agreed with many studies such as $[19,20]$ they screened the most active compounds in macroalgae , biochemical analysis were being undertaken to determine the structure and nature of compounds responsible of the bioactivcompounds of the extracts with high antibacterial activity. Not only the presence of a particular compound which makes these organisms, interesting but also their huge diversity and the possibility of not only harvesting them but also of growing them at different conditions, leading to an enrichment of some bioactive compounds.

\section{References}

1. Kellam, S.J., Cannell, R.J.P., Owsianka,A.M. andWalker, J.M. (1988). Results of a large scale screening programme to detect antifungal activity from marine and fresh water micro algae in laboratory culture. British Phycological Journal.23: 45-47.

2. Selvi, M. and Selvaraj, R. (2000).Antibiotic activities of some Indian seaweeds. Seaweed Research and Utilization, 22 (1-2): 161-166.

3. Van Alstyne, K.L., G.V. Wolfe, T.L. Freidenburg,A. Neill and C. Hicken, 2001. Activated defense systems in marine macro algae: evidence for an ecological role for DMSP cleavage. Mar. Ecol. Prog. Ser., 213: 53-65.

4. Watson, S.B. and E. Cruz-Rivera, 2003. Algal chemical ecology: an introduction to the special issue. Phycologia, 42: 319-23.

5. Blum, J.L. 1956. The ecology of river algae. Bot. Rev. 22:291-341.

6. Dodds, W.K. 1991. Factors associated with dominance of the filamentous green alga Cladophora glomerata. Wat. Res. 25(11):11251132.

7. Sheath, R.G., and Cole, K.M. 1992. Biogeography of stream macroalgae in North America. J. Phycol. 28: 448460.

8. Bellis, V.J., and McLarty, D.A. 1967. Ecology of Cladophora glomerata (L.) Kütz. in southern Ontario. J. Phycol. 3(2):57-63.

9. Burrows EM (1991). Seaweeds of the British Isles volume 2 Chlorophyta. Natural history museum publications London.

10. Leliaert F, Coppejans E (2003). The marine species of Cladophora 
(Chlorophyta) from the South African East Coast. Nova Hedwigia, 76: 45-82.

11. Davis H. Bentley's text book of pharmaceutics (6th edition). 1956:27230.

12. Harborne, J.B., (1973): Phytochemical methods, London. Chapman and Hall, Ltd., Pp. 49-188.

13. Trease, G.E., Evans, W.C., (1989): Pharma cognsy. 11th Edn., Brailliar Tiridel Can. Macmillan Publishers.

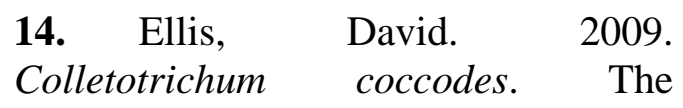
University of Adelaide, Astralia.

15. Agron, B. 2009. Scientists identify two anthracnose pathogens attacking onions. Bureau of Agricultural Research. 10(5):5-12.

16. Campos, G.M., de-Takaki, M.B.S. Diu, Koening, M.L. and Pereira, E.C. 1998 Screening of marine algal from Brazilian. Northeastern coast. Botanica marina. 31:375-377.

17. Prashantkumar, P. Angadi, S.B. Vidyasagar, G.M. 2006. Antimicrobial activity of blue green and green algae. Indian Journal of Pharmaceutical sciences. 68:647-648.

18. Kulkarni, M.K. 1993. A Study of biotoxins of algal origin, Ph.D thesis. Dr. B.A.M.U. Aurangabad (MS)

19. PELÀEZ, F. 2001. Screening of antimicrobial activities in red, green and brown macroalgae from Gran Canaria (Canary Islands, Spain). In International Microbiology, vol. 4, 2001, p. 35-40

20. Mayer,M. ;Rodriguez, A.D. ; Berlinck, R.G.S. and Hamann, M.T. 2007. Marine pharmacology in 20034:Marine compounds with anthelmintic antibacterial, anticoagulant, antifungal, anti-inflammatory, antiplatelet, antimalarial, antituberculosis, and antiviral activities; affecting the cardiovascular, immune and nervous systems, and other miscellaneous mechanisms of action. In Comparative Biochemistry and Physiology, vol. 145, , p. 553-581.

\section{الفعالية التضادية لمستخلص طحلبCladophora glomerata ضد الفطريات الممرضة للنبات}

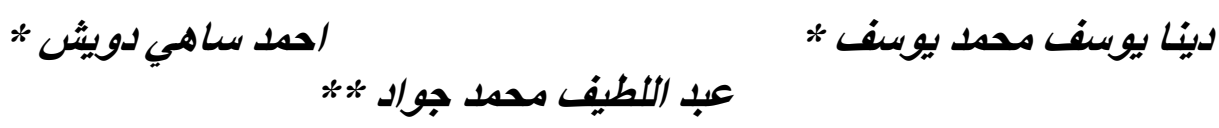

*ققم علوم الحياة /كلية العلوم /الجامعة المستتصرية.

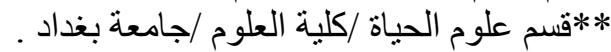

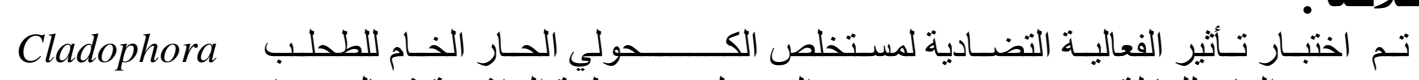
glomerata

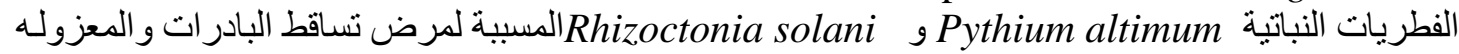
من احد حقول الخيار المغطاة في منطقة اليوسفية .

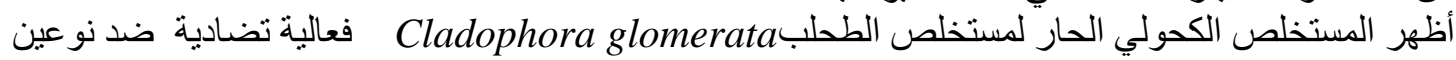

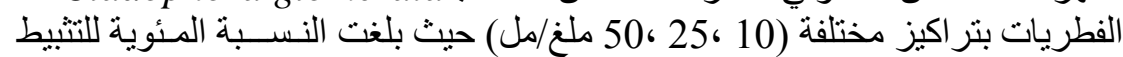

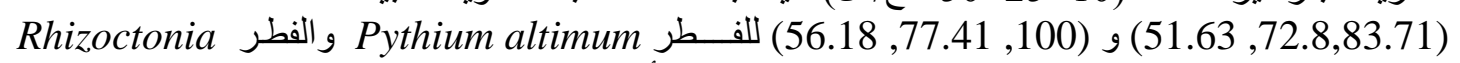

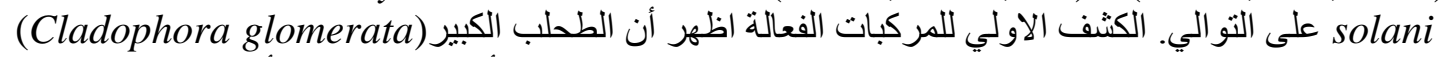

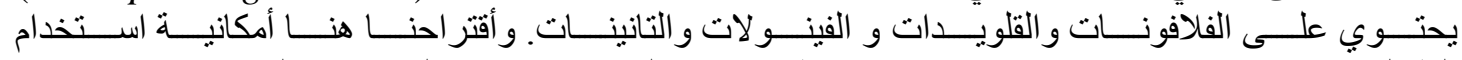
الطحلب(Cladophora glomerata) كمصدر طبيعي ضد المايكروبات في الصناعات الصيدلانية. 